\title{
Arqueología de la ruptura colonial: mouros, chullpas, gentiles y abuelos en España, Bolivia y Chile en perspectiva comparada
}

\section{Archaeology of colonial rupture: mouros, chullpas, gentiles and abuelos in España, Bolivia and Chile in a compared perspective}

\author{
Juan Villanueva Criales ${ }^{1}$, Pablo Alonso González ${ }^{2}$, Patricia Ayala Rocabado ${ }^{3}$
}

\begin{abstract}
Resumen
Este artículo analiza los efectos del colonialismo sobre las maneras en que las poblaciones subalternizadas plantean relaciones de alteridad con sus ancestros y con los vestigios arqueológicos de sus entornos. Desde una perspectiva que cuestiona la interpretación dicotómica y estructural dominante, que concebía estas lógicas de alteridad como producto de dinámicas comunitarias intrínsecas, este estudio visibiliza el rol central de las relaciones de poder históricamente específicas en su articulación. Para ello se comparan los casos del noroeste de la península ibérica, el altiplano boliviano y la región atacameńa chilena, donde existen creencias animistas en mouros, chullpas, gentiles o abuelos, siempre asociados a vestigios arqueológicos, cuya existencia deriva de lógicas similares. Partiendo del proceso de despaganización en Europa y la extirpación de idolatrías en América, con la ruptura de la relación con los ancestros que implicaron, este artículo muestra cómo la modernidad ilustrada, el nacionalismo y el multiculturalismo contemporáneo han incidido en distintas configuraciones identitarias y nociones de ancestralidad en cada caso. La arqueología ha tenido un rol destacado en estos procesos, al subalternizar las construcciones locales de alteridad e intervenir en su patrimonialización.
\end{abstract}

Palabras claves: arqueología, colonialismo, ancestros, multiculturalismo, patrimonialización.

\begin{abstract}
This paper analyzes the impact of colonialism on the ways in which subaltern populations establish relations of sameness and otherness with their ancestors and with archaeological vestiges in their surroundings. From a perspective that questions the dominant dichotomous and structural interpretation that conceived the logic of otherness as a product of intrinsic community dynamics, this study reveals the central role of historically specific power relations in the articulation of identity configurations. This is revealed in the comparative analysis of the northwest region of the Iberian Peninsula, the Bolivian highlands, and the Chilean Atacama region. The populations of the three regions present animistic beliefs in mouros, chullpas, gentiles and abuelos, which they associate with archaeological remains under a common logic. Starting with the Christian struggle against paganism in Europe and the extirpation of idolatry in America, this article demonstrates how enlightened modernity, nationalism and contemporary multiculturalism have led to different configurations of patterns of identity and alterity, as well as alternative notions of ancestry in each case. Archaeology has played a prominent role in these processes, subordinating local conceptions of otherness and partaking in their heritagisation.
\end{abstract}

Keywords: archaeology, colonialism, ancestors, multiculturalism, heritage.

Recibido: 18 noviembre 2016. Aceptado: 27 septiembre 2017

1 Museo Nacional de Etnografía y Folklore, La Paz, BOLIVIA.

Email: juan.villanuevacriales@gmail.com

2 Instituto de Ciencias del Patrimonio (INCIPIT-CSIC), Santiago de Compostela, ESPAÑA.

Email: pabloag10@hotmail.com

3 Research Associate, Abbe Museum, Bar Harbor, Maine, USA.

Email: patricia.ayala.rocabado@gmail.com 


\section{Introducción}

En medio del debate entre la ciencia natural y la explicación científica del mundo, la tradición cristiana y su explicación divina del cosmos, y la persistencia de creencias paganas y animistas sobre la naturaleza y los seres que la habitan, Robert Boyle hacía un apasionado llamado en 1690 contra "la veneración que los hombres generalmente tienen por lo que llaman naturaleza, que ha obstruido e impedido el dominio del hombre sobre las criaturas inferiores", recomendando que, "en lugar de usar la palabra naturaleza, generalmente considerada una diosa, o una especie de semidivinidad, debemos rechazarla, o no usarla" (Boyle, 1738, vol. II, pp. 107-111). Este trabajo de investigación busca arrojar luz sobre el complejo entramado que rodea las relaciones animistas que distintos grupos sociales establecen con su entorno natural, sus ancestros y con la cultura material del pasado en el noroeste de la península ibérica, el altiplano boliviano y la región atacameña chilena. Con distintos grados de intensidad, perviven creencias que vinculan la cultura material del pasado con entidades dotadas de agencia o incidencia en el presente, llamadas moros (o mouros en gallego), gentiles, chullpas, abuelos y otras varias denominaciones. Estos seres animistas reciben, en los tres contextos, connotaciones similares: una relación compleja con las cosmovisiones y relaciones de poder coloniales, y una reconfiguración de estas creencias producida por la arqueología y procesos de patrimonialización.

En este artículo nos preguntamos entonces sobre las distintas lógicas animistas en los casos estudiados, sus semejanzas y diferencias, y el rol que el colonialismo jugó en el proceso de 'extirpación de idolatrías'; tanto el colonialismo del Imperio romano en el caso peninsular como el español en América Latina. Planteamos también si este proceso es simplemente un modo de cristianización, o más bien forma parte de un sistema de gobernanza traspuesto desde España a las colonias con distintas consecuencias para las identidades de las comunidades andinas y su relación con sus ancestros. Cuestionamos, igualmente, el papel de la arqueología como ciencia moderna y occidental encargada de explicar y objetivizar el pasado y su cultura material, preguntándonos sobre su papel en la identificación, ruptura o reconexión de identidades y creencias animistas en cada contexto. Finalmente, reflexionamos sobre la relación entre procesos de puesta en valor patrimonial y la visibilización/invisibilización de estas creencias en cada una de las formaciones sociales estudiadas.

Para arrojar luz sobre estas cuestiones, partimos de tres ejes teóricos. Una primera perspectiva ha intentado comprender el animismo y su erradicación por parte de la Iglesia católica en Espańa y América como un proceso de cristianización y extirpación de idolatrías (Celestino, 1998). Esta perspectiva nos ayuda a comprender el proceso de 'despaganización' en la península ibérica y en los Andes durante el período medieval y el colonial, pero no nos permite analizar los procesos de 'domesticación de la naturaleza' de raigambre racional y científica llevados a cabo por la epistemología moderna y occidental en siglos posteriores. Para ello aplicamos una segunda perspectiva que, siguiendo a Briones (2005), analiza las formaciones de alteridad y las economías políticas que producen las nociones de diversidad en cada contexto. Las formaciones de alteridad resultan de la producción de significados culturales que a la vez naturalizan y definen las características de lo que es propio, bueno y natural, y deslegitiman aquello que es de 'los otros', negativo y simple creencia u opinión, generando segmentaciones de género, nacionalidad, etnia, religión y raza. Así se invisibilizan ciertas cuestiones y se tematizan o patrimonializan otras, a través de "complejas articulaciones entre sistemas económicos, estructuras sociales, instituciones jurídico-políticas y aparatos ideológicos prevalecientes en los respectivos países" (Briones, 2005, p. 17).

Un tercer eje teórico es la crítica de Castro-Gómez (1996) a la noción moderna y occidental de totalidad social, que en otras culturas implica un reconocimiento de la heterogeneidad social, y no necesariamente una subalternización del 'otro' ni el establecimiento de jerarquías e inequidades. El autor nos propone contraponer a la lógica occidental productora de alteridad por binarismos, el análisis de cómo se ha producido la construcción histórica de diferencia a partir de relaciones de poder a lo largo del tiempo. Esto nos permite cuestionar la interpretación que generalmente se ha dado a los 
fenómenos animistas desde las ciencias sociales. Así, el animismo se ha leído tradicionalmente desde una visión presentista que proyecta las categorías de la modernidad occidental a otro tipo de relaciones, interpretando la existencia de seres como moros, chullpas o gentiles como 'pares estructurales' que sirven a los grupos sociales para construir su identidad de forma dialéctica, es decir, por oposición identitaria.

Contra esta visión, nuestra investigación permite comprender cómo estos seres animistas que conviven con las comunidades investigadas son en realidad el producto de una construcción histórica de diferencia y la huella de relaciones de poder con orígenes en la península ibérica y transferidos por las autoridades imperiales a las colonias. Argumentamos que las relaciones de los grupos sociales con los seres animistas han de ser entendidas de forma simétrica como un conjunto de metapatrones o 'relaciones de relaciones', irreducibles a un marco analítico binario característico de la modernidad occidental (Herzfeld, 1992). Estas relaciones, además, no han de ser vistas de forma esencialista como elementos constituyentes de los grupos sociales, sino que son productos de procesos históricos y relaciones de poder específicos (Haber, 2009). Estos procesos generan rupturas con los ancestros, con la materialidad y con las creencias que a su vez rearticulan las formas de vida y aparatos simbólicos de las comunidades.

Para analizar este complejo entramado transnacional, empleamos un enfoque comparativo a partir de la trayectoria investigativa de larga duración de los tres autores en el ámbito de la arqueología y la antropología en cada uno de los tres contextos analizados en Espańa, Bolivia y Chile. La perspectiva comparativa nos permite arrojar luz sobre cuestiones que, de modo aislado, carecían de sentido en nuestros marcos de investigación, como la existencia de gentiles o moros en los Andes. Igualmente, el hecho de que estos procesos sean más recientes en Bolivia y Chile permite reinterpretar la supuesta 'cristianización' de sitios paganos en el noroeste peninsular como un proceso más complejo, en el que también podría haber jugado un papel fundamental la voluntad de reordenar los marcos temporales de las comunidades subalternizadas y romper la conexión con sus ancestros. El artículo comienza con un análisis del caso de los mouros del noroeste ibérico y el contexto general de despaganización y colonización, para después presentar los casos del altiplano boliviano y el área atacameña en Chile, concluyendo con una síntesis reflexiva.

\section{Los mouros del noroeste español: ¿representación de la alteridad, o ruptura con los ancestros en Maragatería?}

A comienzos del siglo XII, el papa Calixto II encargó el monumental Codex Calixtinus para afirmar la localización de Santiago de Compostela como lugar de peregrinación y baluarte católico contra el islam en la península ibérica. El relato llamado Translatio narra la fundación de la catedral y llegada del cadáver del Apóstol Santiago a Galicia, que estaría gobernada por una mujer viuda, pagana y hechicera, la reina Lupa (Llinares García, 1990; Balboa Salgado, 2005). Ésta se opuso inicialmente a la construcción de la catedral y la simbología cristiana que la rodea, pero fue finalmente convencida de abandonar su culto a través de la realización de milagros. Más allá de la leyenda, la catedral se erigió materialmente sobre un anterior cementerio romano y también germánico (Chamoso Lamas, 1982). Las primeras campañas antipaganas las lleva a cabo Martiño de Dumio en el siglo VI con su obra De correctione rusticorum, y en ese período los suevos abandonan el arrianismo y abrazan el catolicismo, organizándose en parroquias y sedes episcopales.

Posteriormente, la emergencia del Camino de Santiago y la consolidación cristiana en siglos posteriores continuaron ese proyecto antipagano, yendo no solo contra la expansión islámica, sino igualmente contra la multitud de creencias paganas precristianas que mantenían las gentes del noroeste. También el capítulo IV de la Crónica de Turpin en el Codex narra cómo los islámicos, antes de su huida hacia el sur, escondieron todos sus tesoros bajo tierra. Esto explicaría otra característica asociada a los mouros o moros del noroeste ibérico: su vinculación inextricable con la riqueza y el oro enterrados. Las historias sobre los moros se entremezclan con narrativas cristianas, que intentaron desde sus inicios recodificar la materialidad y discursividad 'pagana' en términos 
de la mitología bíblica. Este proceso pudo haberse iniciado con la primera expansión del cristianismo con el Imperio romano, y más tarde potenciado debido a una posible revitalización del paganismo -y la lucha contra él- en tiempos medievales y modernos (Fernández Conde, 2000, pp. 498-499). En Europa, la asociación del paganismo con ritos no cristianos e idolatría sirvió a la Iglesia como retórica legitimadora para combatir estas creencias (Celestino, 1998). La extirpación material de idolatrías se realizaba mediante la cooptación de lugares de culto pagano, en antiguos poblados, cementerios o sitios sagrados como fuentes, picos, manantiales o rocas, probablemente vinculados a los ancestros de las comunidades. En estos sitios se construían ermitas y capillas, a la vez que se cooptaban los rituales del calendario pagano o mártires paleocristianos mediante la creación de romerías y procesiones, o el reemplazo de deidades paganas por personajes cristianos, como Santiago Matamoros. Muchas de estas deidades tenían poder hidróforo, como San Lourenzo en Galicia, portador de lluvias.
También cerca de Maragatería se da el caso del santuario de Castrotierra, erigido sobre un castro (Figura 1). Los castros son poblados fortificados característicos del noroeste ibérico, fechados en la Edad del Bronce y del Hierro, aunque existen ejemplos posteriores, romanos y medievales. Castrotierra es uno de los santuarios de mayor importancia de León, al que peregrinan las comunidades en tiempos de sequía implorando la lluvia a la Virgen de Castrotierra, también llamada 'Diosa de la Lluvia', clara reminiscencia de la vinculación pagana entre naturaleza, animismo y feminidad. Igualmente, en el pueblo de Foncebadón, en Maragatería, se encuentra la Cruz de Ferro y una capilla al Apóstol Santiago en el Camino de Santiago, emplazada en el lugar donde se realizaban aquelarres los días de San Felipe, según la tradición oral.

El proceso de cristianización no se explica sin entender la importancia del catolicismo en la identidad española desde el siglo XVI, cuando la Inquisición era la única institución que operaba en todo el te-

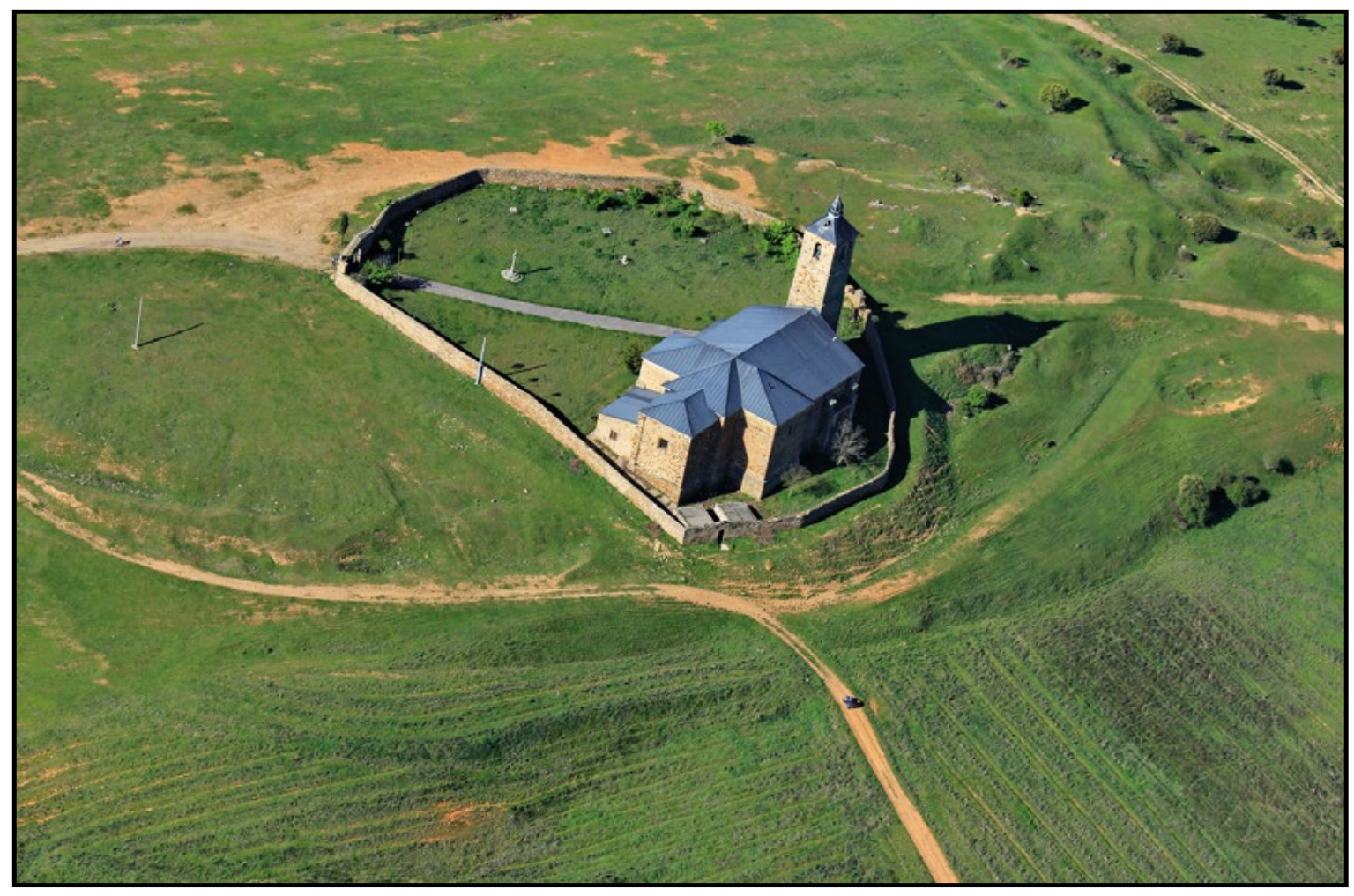

Figura 1. Santuario de Castrotierra emplazado sobre un castro prerromano. Fuente: Pablo Alonso G. 
rritorio dada la falta de integración territorial y cultural. Un sentimiento protonacionalista surgía en oposición a aquellos considerados 'otros': judíos y moriscos, pero también paganos, como evidencia la persecución y exterminio de brujas (Goode, 2009; Alonso González, 2015). La conquista de América fue fundamental en esta configuración identitaria, vinculada a la ida y vuelta de ideas, creencias, miedos y personas. Para Grosfoguel y Mielants (2006), la Controversia de Valladolid y el debate entre Las Casas y Sepúlveda sobre la condición de los aborígenes americanos sentó las bases de las políticas de subalternización de los siguientes cinco siglos. Las Casas anticipaba el racismo cultural al considerar que los aborígenes tenían alma y, por tanto, podían ser cristianizados -como los paganos-. Para Sepúlveda, antecesor del racismo biológico, los aborígenes carecían de alma y podían ser explotados o exterminados -como ocurrió con las brujas-. Siguiendo a Federici (2010), ambas posturas se combinaron durante la conquista. Primero, se consideraba que los indígenas eran convertibles al cristianismo, y por lo tanto se exportaron las técnicas de cooptación material y simbólica para realizar extirpaciones de idolatrías y dioses locales. Después, durante el siglo XVIII, se entrelazan el racismo biológico con la ideología de la brujería, representándose el diablo como un hombre negro y tratándose a los negros como diablos.

Así, afirma Federici, "Los homólogos de la típica bruja europea no fueron, por lo tanto, los magos del Renacimiento, sino los indígenas americanos colonizados y los africanos esclavizados" (Federici, 2010, pp. 272-273). No solo se usaron en América técnicas contra la brujería sino que, según Parinetto (1998), la experiencia en las colonias llevó a los gobernantes españoles y europeos a la convicción de la existencia de poblaciones enteras de brujas y diablos, lo que legitimaría la aplicación de técnicas de exterminio masivas como las usadas en América, y otras como los Autos de Fe. Pero la extirpación de idolatrías nunca llegó a ser completa en Europa, especialmente en zonas periféricas y de estatalización débil y tardía como el noroeste ibérico. En el norte de Portugal y en las actuales regiones españolas de León, Asturias y Galicia, han subsistido hasta la actualidad grupos con una forma de alteridad históricamente específica, comunidades tradicionalmente denominadas como campesinas y preindustriales, subalternizadas por el Estado, con una vinculación fuerte con su territorio circundante. La cultura material jugaba un papel central en estas comunidades, ya que en ella y en el espacio se incrustaban historias individuales y colectivas fundamentales en la ordenación de narrativas, normas y recuerdos. Hoy día solo los más ancianos mantienen una visión mitológica del entorno, entreverada ya con lógicas modernas debido a la implantación de un sistema educativo en zonas rurales y la creciente alfabetización e inculcación de la historia nacional desde finales del siglo XIX.

En Maragatería, región donde hemos realizado trabajo etnográfico desde 2006, y en el noroeste peninsular en general, podemos dividir las creencias animistas entre 'internas', restringidas al interior de los pueblos, y 'externas', fuera de las zonas de hábitat $\mathrm{y}$ asociadas generalmente a vestigios arqueológicos. Entre las primeras subsiste la creencia en brujas o meigas, duendes, hadas y demonios. En Lagunas de Somoza hay una 'casa enduendada', edificio en ruinas sobre el que varias personas afirmaban en nuestras entrevistas haber oído balidos de cordero, o ver gallinas sin cabeza y monedas de oro caer del techo. En Maragatería se teme el 'mal de ojo' de las brujas, y abundan los remedios protectores como escapularios y cédulas benditas con escamas de pescado. También se teme a los diablos, reñuberos o ñublaos, de los que se dice que atacan principalmente al ganado. Por ello, se protegían los establos con losetas de piedra con grabados de cuatro o seis pétalos a la entrada, que imitaban las estelas funerarias grabadas por los romanos en sus lápidas. También eran habituales los pagos a hadas en las fuentes de los caminos, como el Camino Gallego y el de Santiago, que atraviesan la comarca.

Más nos interesan aquí los habitantes animistas del territorio circundante a los pueblos, los mouros (en gallego) o moros (en castellano) usándose ambas acepciones indistintamente en el caso de Maragatería. En principio, los moros no están vinculados con los musulmanes, islámicos o sarracenos históricos, sino que más bien derivan de prácticas exotizadoras en el período de reconquista española durante el medievo, en el que 'lo moro' era considerado como paradigma extremo de alteridad (Quin- 
tía Pereira, 2016). Los moros no son enemigos de los labriegos, que no les temen, aunque presentan rasgos no humanos, y pueden poseer poderes mágicos y un atractivo sublime. Comparten lugar en la cosmovisión campesina con ánimas y hadas, que habitan fuentes, pozos y bosques. Los moros habitualmente se vinculan con sitios arqueológicos, y también se dice que ellos mismos los construyeron (López Cuevillas y Fraguas Fraguas, 1955, pp. 280-282). Bajo los sitios arqueológicos estarían sus viviendas y acumulaciones de oro o riquezas (vinculación inscrita en su etimología: m-ouro, m-oro; del latín, m-aurus; oro=aurum), que pueden recibir distintos nombres como 'carro dorado', 'caldero', 'caballo' o 'serpiente de oro'. Esta vinculación con el oro podría derivar tanto de las explotaciones auríferas romanas dispersas por el noroeste ibérico como de las leyendas que hablaban del modo en que los musulmanes históricos soterraban sus tesoros, o de los hallazgos de tesorillos por los campesinos en sus trabajos agrícolas. La supuesta existencia de estos tesoros ocultos por los moros hizo que, durante siglos, se realizasen cientos de excavaciones en su búsqueda, llegando a surgir gacetas de tesoros y cazatesoros, conocidos como chalgueiros en Asturias (Suárez López, 2001). Incluso los eclesiásticos, supuestamente encargados de la extirpación de estas creencias, participaban en las excavaciones. Así, en el pueblo maragato de Pedredo la documentación local del siglo XVII habla de cómo un sacerdote de Turienzo pedía permiso para excavar en busca de un tesoro en La Corona, un castro. La conexión con América es aquí importante, ya que, durante el siglo XVII, hidalgos y curas procedentes de América, conocedores de las riquezas precolombinas que aparecen en enterramientos y túmulos, reinterpretaban las mámoas prehistóricas gallegas en ese sentido e inician excavaciones en busca de oro. Por ello resulta habitual, en las excavaciones de castros del noroeste, que las personas consideren que los arqueólogos van a buscar tesoros.

A través de sus propias prácticas, los campesinos asocian los objetos arqueológicos que aparecen en estos yacimientos a actividades de los moros, es decir, se trata de leyendas y costumbres reelaboradas constantemente por las personas en sus relaciones cotidianas con el espacio. Así, los torques llevan a hablar de que las moras se peinan o tienen calde- ros, los lingotes o hachas a que juegan bolos, las fíbulas con grabados a que poseen animales, o las monedas a reforzar la vinculación entre moros y tesoros (González Álvarez, 2011, p. 142). Pero los moros también realizan actividades cotidianas, y pueden ser, en el caso de las moras, atractivas, hermosas o peligrosas. En Morales, una anciana me aseguraba que, en una ocasión, "la mora bajó aqui a lavar la ropa" (entrevista 2, noviembre de 2008), apuntando a un reguero. Cuando desentierran tejas con sus arados, los campesinos suelen vincular este hecho con los tejados de las casas de los moros, que viven bajo tierra.

Esta visión mitológica es posible por la inexistencia de una visión linear y cuantitativa del tiempo, lo que impide la existencia de conceptos abstractos como el de prehistoria en estos grupos. Esto se evidenciaba en una conversación entre un arqueólogo aficionado y un grupo de ancianos de Chana sobre la 'Piedra de la Medida', sitio arqueológico con grabados prehistóricos:

-(Persona 1): Si, haciamos bastantes cazoletas en las piedras, ya ves, para no pasar el día mirando para las ovejas.

-(Aficionado): Y claro, haciais las cazoletas justo igual que los gallegos y los otros de Europa claro... en vez de poner las iniciales de la novia haciais cazoletas.

-(P. 2.): ¿La caldera de la mora no la encontraste? Ahora está bueno para entrar, está el monte limpio.

-(Aficionado): Una cosa es lo del pastor, pueblo de Chana... se veía bien la firma... pero se ve bien lo que haciais los pastores hace unos años, de lo que se hacía hace miles de años. $\mathrm{Na}$ die graba un circulito con un punto en el medio. Eso igual fue un pastor, pero hace cuatro mil años. Igual era nuestro ancestro.

-(Todos rien): ¡Sí, claro! ¡Venga, hombre! Que no, que no...

-(Aficionado): Entonces, ¿cómo explicáis que venga gente y no vea la iglesia y vea las piedras? -(P. 4): Bueno, si no son creyentes pues normal que no vengan a la iglesia.

-(Aficionado): Y la piedra de la medida... ¿eso quién lo hizo? 
-(P.4 ): No, claro, eso un pastor... Dicen que ahi la mora es donde lavaba. No sé.

-(P.3): Sí, eso es el lavadero la mora.

Los moros forman parte de una ordenación temporal específica de estos grupos. En el Alto Minho, De Pina Cabral (1989) describe una primera fase referida a 'lo actual', temporalmente contemporánea y habitada por la gente, y otra que comprende 'lo de antes', habitada por los antiguos. En Maragatería, los moros también se asocian a 'lo de antes', pudiendo haber reemplazado otras denominaciones y personajes como antiguos, galigriegos, gigantes o gentiles (González Álvarez, 2011, p. 139; Álvarez Peña, 2007, pp. 225-226). En Maragatería, los moros no son considerados parte del 'nosotros' del campesinado, es decir, no son ancestros. Esto se evidencia en que la presencia de moros se atribuye a restos arqueológicos que se consideran 'otros', como explotaciones mineras romanas o castros. Sin embargo, despoblados o barrios abandonados del alto o bajo medievo, cementerios o ermitas en ruinas son concebidos como parte de la materialidad de los ancestros de la comunidad. Algo que se percibe fácilmente en el rechazo existente a las excavaciones arqueológicas dentro de los pueblos en estos espacios, mientras las investigaciones en castros no molestan a nadie - en los castros solo hay tesoros-. Es decir, existe una ruptura entre los espacios considerados como pertenecientes a los ancestros y aquellos otros de los que existen leyendas y referencias espaciales habitados por moros.

La Iglesia intentaría extirpar estas creencias paganas, tanto mediante la cooptación de la cultura material como por la explicación de los sitios arqueológicos a través de seres mitológicos cristianos. Por ejemplo, bajo los fosos de un castro en Val de San Lorenzo hay una piedra semienterrada con un grabado de una media luna de un metro de diámetro (Figura 2). La piedra, que no aparece en los inventarios arqueológicos, es bien conocida en el pueblo. El anciano que me llevó a conocerla afirmaba que se trataba de la pisada del caballo de Santiago Matamoros.

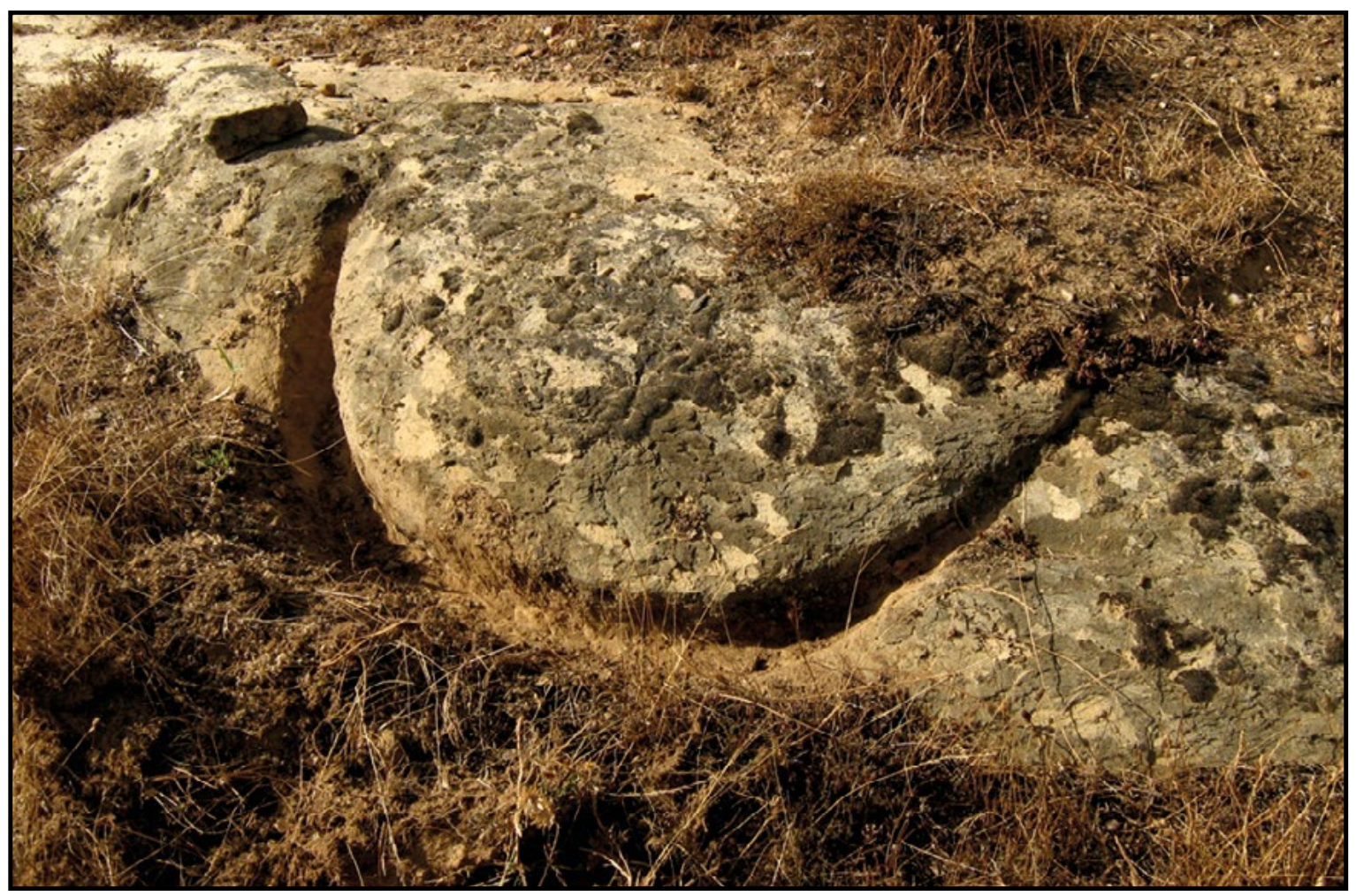

Figura 2. Grabado a la entrada de un castro prerromano en Val de San Lorenzo. 
Ésta es una explicación recurrente para los petroglifos prehistóricos del noroeste peninsular, y entra en relación con el escaso interés del campesinado de esta zona por el arte rupestre en comparación con los castros, cuevas y túmulos megalíticos (Aparicio Casado, 2002).

Las escasas interpretaciones académicas sobre los moros -más allá de calificarlos como simple superstición o folclore- suelen considerarlos como 'otros' en oposición a la identidad campesina, un símbolo de asimetría en la que el campesino está en una situación desventajosa (Freán Campo, 2016). González Reboredo (2004) concluye en Galicia que los moros serían el otro extraño, antiguo, una especie de tribu mágica con poderes. Desde el estructuralismo, Llinares García (1990, p. 21) cree que los moros más bien reflejan las preocupaciones y relaciones sociales de la propia comunidad campesina, y en particular las que les resultan más preocupantes o conflictivas. Esto seguiría la línea interpretativa de Ingold (2013) en relación con la mitología de los dragones en la Edad Media: la cuestión no es si los dragones existían o no sino que, de hecho, servían para expresar símbolos, miedos y relaciones sociales que eran reales. En general, discrepamos de estas interpretaciones al concebir la construcción identitaria campesina de forma dialéctica, idealista, moderna e ilustrada.

Desde la visión de Viveiros de Castro (2010), afirmar que el 'multinaturalismo moro' sirve simplemente para reafirmar la identidad campesina por oposición, no es más que proyectar la episteme moderna a modos de existencia otros e históricamente específicos. Siguiendo la teoría de la colonialidad del poder (Castro-Gómez, 2005), podemos plantear una interpretación alternativa. Estas supuestas formas de alteridad probablemente sean más bien construcciones de diferencia producto de relaciones de poder históricas, vinculadas a una ruptura doble desencadenada primero por el cristianismo y después por la razón ilustrada: ruptura con la creencia en el afuera (en naturalezas animadas, en contra de la Biblia que presupone una naturaleza inerte, creada por Dios, o la ciencia, que explica las leyes de una naturaleza inerte), y ruptura con los ancestros, que pasan a ser considerados 'otros' espacial y temporalmente.
En el caso español, es posible afirmar que el multinaturalismo moro tiende a disiparse debido a la carencia de una diferencia étnica y racial por parte de los grupos campesinos respecto a la identidad mayoritaria española. Así, los moros desaparecen con la muerte de las personas más ancianas. La falta de continuidad étnico-racial también explicaría el escaso interés en la cuestión por parte de arqueólogos y antropólogos más allá de la tradición arqueológica nacionalista en Galicia o País Vasco. Históricamente, podemos hablar de un momento inicial en el que resultaba difícil separar los discursos de religión y ciencia en la interpretación arqueológica, en paralelo a la confusión entre discursos bíblicos y científicos. Marín Suárez (2005) muestra cómo en la primera excavación con memoria arqueológica publicada sobre un castro en Asturias por José María Flórez (Coaña en 1878), se tenía en cuenta la tradición oral de los habitantes de la zona y se incluía la misma en las interpretaciones arqueológicas, sin conseguir de hecho separar dato el científico de la creencia popular. Con la gradual profesionalización de la arqueología en el noroeste ibérico, la tradición oral se irá adscribiendo al llamado 'folclore', separándose de la explicación científica.

Los muchos arqueólogos que trabajaron en Maragatería a lo largo del siglo XX no mencionaban la tradición oral en sus descubrimientos, memorias e interpretaciones, desde aficionados hasta profesionales académicos y de contrato, entre otros Luengo Martínez, Carro y Carro o Domergue. Pese a esto muchos de ellos se basaban en la tradición oral para encontrar yacimientos. Como denuncia González Álvarez (2011) en Asturias, durante la época franquista los arqueólogos solo tenían en cuenta la cosmovisión campesina en las tareas de prospección y catalogación de yacimientos, pero generalmente la menospreciaban como simple superstición; situación similar a la de Galicia (Arizaga Castro y Ayán Vila, 2007). La generalización del procesualismo en los noventa y dos mil relegó la tradición oral a un segundo plano, reemplazada por la búsqueda de 'datos duros' tipológicos, tafonómicos o arqueométricos.

En síntesis, la cosmovisión históricamente específica de los grupos no socializados en el mundo moderno del noroeste ibérico está lejos de pasar por un 
proceso de patrimonialización, o aun de estudio comprehensivo y crítico. Solo algunos arqueólogos con una orientación social han tenido en cuenta la tradición oral, pero ésta sigue siendo generalmente considerada como una forma de superstición en vías de desaparición, o bien mero folclore que puede simplemente ayudar a la localización de sitios arqueológicos. Lejos de establecer una simetría con las comunidades, los arqueólogos profesionales $\mathrm{y}$ académicos tienden a subalternizar al menos en tres sentidos a los habitantes de los espacios donde se realizan trabajos: convirtiéndolos en trabajadores manuales temporales en las excavaciones; no representando su cosmovisión en museos y sitios museificados, sino más bien purificando los 'datos puros' de la supuesta visión 'folclórica' campesina, y finalmente, considerando sus cosmovisiones históricamente específicas como supersticiones, folclore o simplemente como creencias pasadas tendentes a la desaparición, en una forma de alocronía (Fabian, 2002). Al contrario de Atacama, por ejemplo, no existen casos de arqueólogos posprocesualistas que hayan reclamado estas visiones como legítimas y las hayan vinculado a las demandas de las propias comunidades. Demandas que, por otra parte, no existen vinculadas como tal a una forma sociocultural distintiva por parte de los campesinos. Esto es así debido probablemente a su falta de 'diferencia' étnico-racial, a la desaparición del sector agrícola y a la creciente preponderancia de formas de raciocinio, individualización e instrumentalismo propias de la modernidad occidental entre las gentes del noroeste ibérico. En paralelo, cabe mencionar que sí se ha producido a nivel social un movimiento posmoderno New Age que convierte a estos seres mitológicos (como las meigas) en recursos patrimoniales, pero preservando solo el contenido simbólico aislado como patrimonio, sin la cosmovisión mítica donde cobraba sentido (Jiménez-Esquinas, 2013).

\section{Chullpas y gentiles: trasponiendo los habitantes del 'otro tiempo' al altiplano boliviano}

Chulpa es un término aymara con numerosas acepciones, la más temprana haciendo referencia a un cuerpo muerto encerrado en un fardo tejido y también a una torre funeraria de piedra o adobe
(Bertonio, 1879 [1612], p. 92). Ambas manifestaciones caracterizan las costumbres funerarias de los habitantes del altiplano actualmente boliviano, entre los siglos XIII y XV (Pärssinen, 2005). Bandelier (1910) es el primer arqueólogo en emplear el término al investigar el circun Titicaca; influido por las percepciones locales, asigna las 'ruinas toscas' a los chullpa y aquellas mejor construidas al Inca, denominando Chullpa al período Preincaico y a su cerámica asociada. Paralelamente, en el altiplano central Posnansky (1912) usaba el término chullpa en referencia a las torres funerarias, interpretándolas como viviendas en base al denominativo local: chullpa uta (casa del chullpa).

Antes de ingresar a otra acepción del término, notemos que abundantes registros etnohistóricos sugieren lazos ceremoniales entre las poblaciones andinas y los restos humanos preservados hacia el siglo XVI. Entre otros, Salomon (1995) emplea estas referencias para resaltar el carácter sacro de los restos humanos, 'fundadores' de los cuerpos sociales o ayllus y ligados mediante parentesco mítico a deidades o wak'as. La interacción con los cuerpos, su alimentación, rogativas en procura de lluvias, cosechas y ganado, consultas oraculares, y la familiaridad con que los andinos se dirigían a estas 'momias', son sintomáticas de un culto al ancestro. Para el caso altiplánico, Polo de Ondegardo (1916 [1562], p. 194) refiere:

Es cosa común entre indios desenterrar secretamente los defvntos de las iglesias, o cimienterios, para enterrarlos en las Huacas, o cerros, o pampas, o en sepulturas antiguas, $o$ en su casa, o en la del mismo defunto, para dalles de comer y beber en sus tiempos. Y entonces beven ellos, y baylan y cantan.

En el altiplano, estas 'fiestas de los difuntos' tienen correlatos arqueológicos: las torres funerarias preincaicas e incaicas, flanqueadas por plazas destinadas al festejo y/o asociadas a fragmentería cerámica de servido (Villanueva, 2015) (Figura 3). Este comensalismo chullpario marca un quiebre con períodos anteriores al siglo XIII, cuyas arquitecturas funerarias no permitían preservar ni comunicarse con el muerto (Isbell y Korpisaari, 2012; Machicado, 2009). 


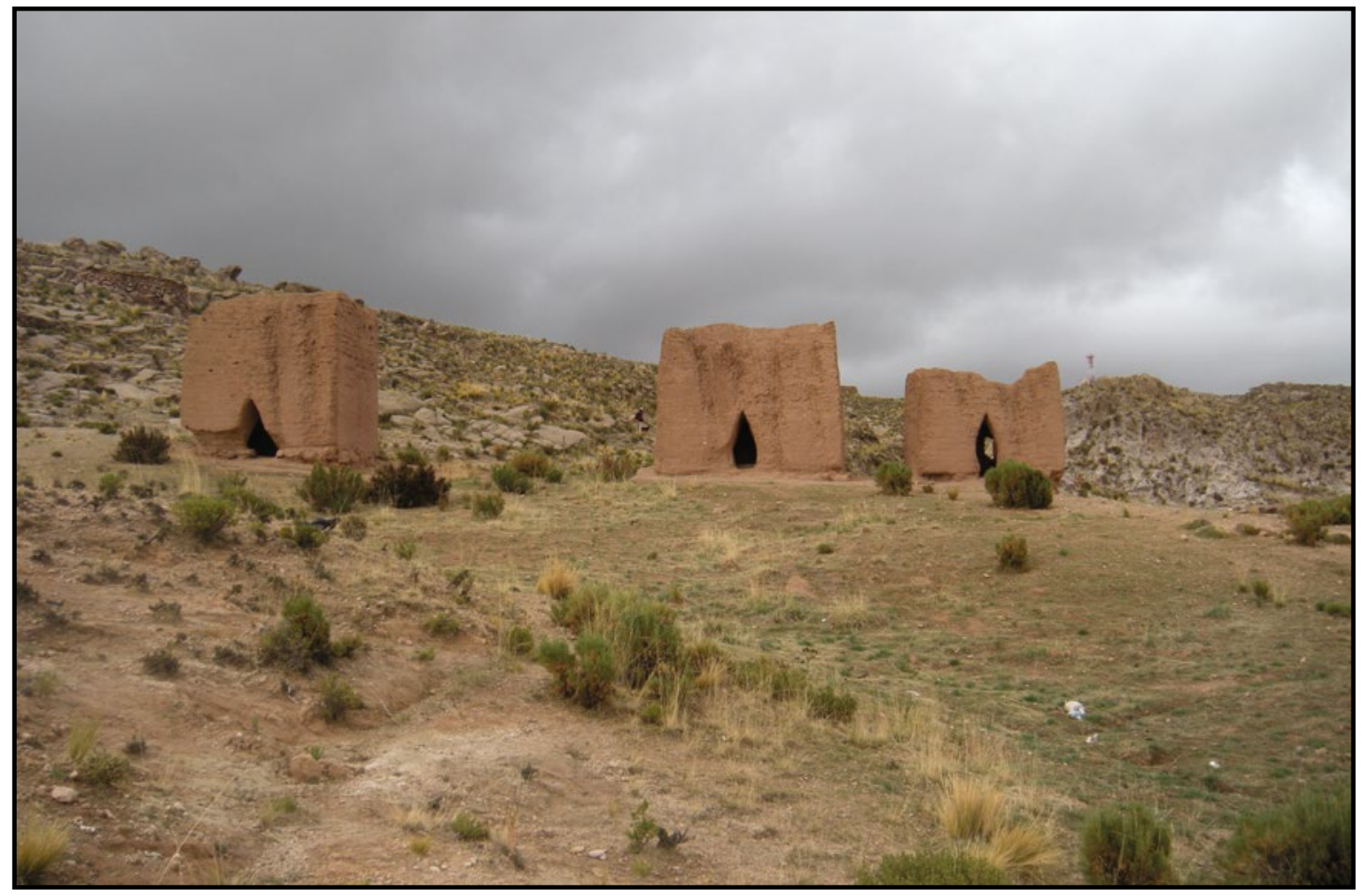

Figura 3. Remanentes de torres funerarias o chullpas en Curahuara de Carangas, Oruro.

Pero existen otras traducciones de chullpa. En su etnografía entre los chipayas del altiplano Intersalar, difundida verbalmente en 1931 y luego transcrita por Pauwels (1998, p. 68), Métraux provee la primera versión registrada del mito de los Chullpas:

Antes, en los tiempos muy remotos, vivían en estas tierras los chullpas. Sus casas tenían las puertas dirigidas hacia el Oeste, pero como el sol los molestaba cambiaron de orientación y las pusieron al Este. El Dios Sol salió entonces al Oriente y mató a todos los chullpas, que perecieron en sus casas donde los hallamos hoy [...].

Aunque el mito proviene de un contexto uru y no aymara, está sumamente extendido entre las poblaciones altiplánicas, influenciando incluso el imaginario de las clases letradas bolivianas a través de Díaz Villamil y su novela El Tesoro de los chullpas, de 1939. Pero Métraux recalca otro elemento: la sinonimia entre chullpa y gentil, o chullpar y genti- lar (Pauwels, 1998, p. 49), que había detectado ya Bandelier (1910) en el Titicaca. Jintili o gentil es un préstamo del castellano colonial, como muestra esta referencia de Ávila (1966 [1598?], p. 255): “[...] lo lleva él mismo, si puede, adonde está enterrado su progenitor que comúnmente es en alguna cueva porque era gentil, y allí echa el dicho ídolo".

Hardman (1984, p. 1) sugiere que en el aymara contemporáneo se llama jintiluta a las casas de los gentiles, y que es común el término moro para referirse a los no bautizados. Tanto el chullpa como el gentil, antiguo o moro se asocian con las ruinas antiguas, y esta asimilación opera probablemente en el contexto de las Reformas Toledanas y la extirpación de idolatrías (siglos XVI a XVII). Las torres funerarias pueden contarse entre las primeras víctimas de este proceso, según instruye el virrey Toledo en 1573: "Ordeno y mando que cada juez en su distrito haga que todas las sepulturas de torres que están en bóvedas en las montañas, e sierras, se derruequen e haga hacer un hoyo grande donde se pongan revueltos 
los huesos de todos los difuntos que murieron en su gentilidad" (Gisbert, 1999, p. 15).

Desconocemos cuantas torres fueron efectivamente derruidas, pero ciertamente existen escasos vestigios de comensalismo chullpario colonial, sugiriendo un cese abrupto. Pero los gentiles poblarán también los asentamientos fortificados o pukaras y 'pueblos viejos' en general (Hardman, 1984, p. 9). El reasentamiento que impone el régimen toledano en pueblos nuevos dominados por el poder hispano podría explicar esta ampliación del espacio chullpa. Los casos coloniales mejor documentados de culto a los ancestros vienen de aldeas reasentadas que mantienen residencia satélite y ceremonias clandestinas en los 'pueblos viejos' (Salomon, 1995). Para el aparato colonial, caracterizar las ruinas como espacios de gentiles permite enajenar a los locales respecto de sus antiguas prácticas ceremoniales y residenciales. Este fenómeno forma parte de una cristianización general del paisaje andino: las wak'as de los cerros serán coronadas por calvarios o capillas de la Virgen María, Santa Bárbara o Santiago; aun la Vía Láctea, importante en la cosmovisión prehispánica como lugar de wak'as estelares, será reinterpretada como el camino de Santiago (Sánchez et al., 2015).

Ahora bien, ¿qué atributos de lo chullpa permiten operar esta enajenación? Ante todo, estos entes son malos, peligrosos (Hardman, 1984). A diferencia de los indios cristianos, estos gentiles no bautizados asumen el lado presolar y salvaje de una dualidad. Este salvajismo puede ubicarse en la comida chullpa, como ilustra claramente un testimonio del altiplano de Lípez (Gil García, 2005, p. 196): "Como nosotros son. Únicamente no son... Sin sal saben comer. ¡Sin sal! Por eso son... ¡Muros son, pues! Sin bautizar. Nosotros, claro, comemos con sal; somos bautizados, cristianos. Ellos, muros, sin bautizar. Así no más son”.

Ciertos rasgos culinarios sugieren un perspectivismo chullpa (sensu Viveiros de Castro, 2010). La ajara o quinua silvestre es la quinua de los chullpas (Gil García, 2014); en el altiplano central, el ullucu, tubérculo pequeño de consumo potencialmente tóxico, es su papa. Su ganado es de zorros, vicuñas o vizcachas, animales sallqa o criados por la tierra o los montes, en contraste con las llamas uywa, de crianza humana (Arnold y Yapita, 1992).
Los chullpas son mágicos; son sumamente fuertes o construyen hablando con las piedras (Gil García, 2005). Su forma de seducir es usualmente el oro, bien tradicionalmente valorado por el europeo (Hardman, 1984). Los hallazgos de oro chullpa y gentil son propiamente europeos, aunque adscritos al inca: la campana, la yunta, el cinturón o el bastón de oro del Inca Manco Cápac. Aquí se relativiza la oposición inca-chullpa de Bandelier, y el gentil pasa a incorporar todo lo prehispánico. El sol "civilizador" que mata a los chullpas no sería el Inti incaico; en el contexto evangelizador, podría ser la luz de Cristo.

En todo caso, el oro chullpa atrae las desgracias, cualidad potentemente enajenante. El tesoro causa la división, el 'miramiento' en una comunidad acostumbrada a redistribuir la riqueza. Pero sobre todo, el contacto con los gentiles produce chullpa tuullu o chullpa usu, enfermedades caracterizadas por dolores de huesos, fiebres, erupciones cutáneas y eventualmente la muerte. En el altiplano Pacajes, mientras excavábamos entierros con pobladores locales, sobrevino una fuerte ráfaga de viento. "Chullpa viento es" nos dijeron, indicando que evitemos aspirarlo.

Los gentiles son profundamente herejes y por tanto antropófagos, como detecta Gil García (2005) en el marco de una 'guerra antigua' donde los chullpas se devoran. Pero en otros cuentos, la peligrosidad de convivir con un gentil subyace en la amenaza de ser devorado o encerrado bajo tierra, como muestra este fragmento sobre unos músicos:

Ya estaban muy lejos de la comunidad, ahí descansaron en la falda de un cerro. Ahí, un gran señor había llegado así diciendo "Hermanos, visítenme a mí, ésta es mi casa, en ahí descansen, coman, tomen" diciendo. Entonces ellos bien felices en ahí comieron, así ahora ese dueño dijo, "bueno la cerraremos la puerta hace frío" diciendo. Pero otro había ido a orinar, lejos había ido, de ahí cuando regresó no encontró a sus compańeros pero la música se escuchaba de adentro; había buscado mucho "donde están ustedes" diciendo. De su comunidad a dos chicas había traído para pagarle a ese 
gentil; seguía escuchándose esa música, pero no nunca. No lograron sacar nunca, por gusto encima llorando mujeres e hijos. Entonces no había sido gente, ese había sido gentil dicen, de qué tiempo habrá sido, ese gentil engañó por encanto a ese grupo. (Hardman, 1984, pp. 8-9)

Un aspecto fundamental del gentil es ser 'de otro tiempo'. En la comunidad de Condoramaya, en 2008, recogimos el término 'limbo tiempo', tiempo de los no bautizados, en referencia a los chullpas. Además, el gentil tiene 'encanto'. Es un gran señor, un mozo blanco y guapo, o una mujer seductora. Sugerentemente, a inicios del siglo pasado era extendida en el altiplano la historia de Juan Rubio, un español que en tiempo de los chullpas vino del este para prevenirles sobre la aparición del sol (Bandelier, 1904).

Hardman (1984) interpreta la hispanidad del gentil como una interpretación local de la maldad de los españoles. Nosotros discrepamos basados en las notables similitudes entre el gentil y los mouros de Maragatería descritos arriba (hermosura, vínculos con el subsuelo, lo antiguo y el oro). La hispanidad del gentil podría deberse a una trasposición del gentil europeo al paisaje andino durante la evangelización. Podría delatar la aplicación de dispositivos ya probados en la despaganización de la península al nuevo contexto andino. Sin embargo, no podemos descartar una inserción más espontánea del gentil, pues el clérigo raso que evangeliza el altiplano podría cargar su propio bagaje pagano (Bouysse-Cassagne, 1997).

El chullpa o gentil, este 'otro' encantador y mortal, ser 'de otro tiempo' habitante de los sitios antiguos, alejó a las poblaciones locales, mediante el temor, de aquello antes venerado. Sin embargo, esta enajenación parece incompleta, quizás por el abandono eclesiástico del campo a partir de las Reformas Borbónicas (siglo XVIII). En un proceso reminiscente de la romería de Castrotierra en Espańa, sucede lo siguiente en el altiplano Carangas:

Cuando no llegan las lluvias las autoridades sacan a los difuntos y se recuerda a la gente antigua, realizan el sacrificio de llamas y hacen también constantes brindis (ch'allas), rodean chullpares dando vueltas. Ellos se agarran por medio de sogas y ondas [sic], los jilaqatas hablan con los chullpas diciendo: "wawaqallutaki aka qarpawapataki jan jallu purjiti" (para las chacras de los comunarios no llega agua) (López y Ríos, 1999, pp. 60-61).

El 2008, en el altiplano Pacajes, detectamos que ante un exceso de lluvias, los locales extraían huesos de las torres funerarias, emplazando cigarrillos entre los dientes de los cráneos de modo idéntico al descrito por Bandelier (1910). Los poderes hidróforos de los gentiles y chullpas los emparenta con reconocidos espíritus ancestrales de las montañas nevadas, llamados achachilas (abuelos) o uywiris (criadores). En ese contexto adquiere sentido la exclamación enternecida -cercana al caso atacameño que exploramos enseguida- de una señora que excavaba con nosotros, ante las reducidas dimensiones de un esqueleto:

\section{- ¡Wah, mirá a ver! ¡Tan chiquito habia sido, el abuelito!}

La pervivencia de cierta relacionalidad con un pasado nunca ausente, dotado de ánima y de agencia sobre el presente (Figura 4), sugiere que el objetivo colonial de ruptura no fue completado. Sin embargo, la inserción del gentil como dispositivo enajenador ocasionó entre las poblaciones locales una conducta conservadora hacia 'lo antiguo', cuyo giro más reciente involucra a los arqueólogos bolivianos, que poco han hecho por incluir percepciones locales en sus narrativas. En la etapa de arqueología nacionalista (1950-1980), Ponce Sanginés (1980) intenta encumbrar a Tiwanaku como un referente de orgullo patrio, sucedido por una época oscura de 'señoríos' aymaras. Como correlato político de esta narrativa, apropiándose del pasado 'brillante', las élites mestizas urbanas adquieren legitimidad para guiar a los 'mestizos campesinos' (indígenas descendientes del pasado 'oscuro') hacia la modernidad. En estas décadas las comunidades indígenas se sindicalizan, mientras la crisis y una valoración de la vida urbana impulsan una creciente migración campo-ciudad. 


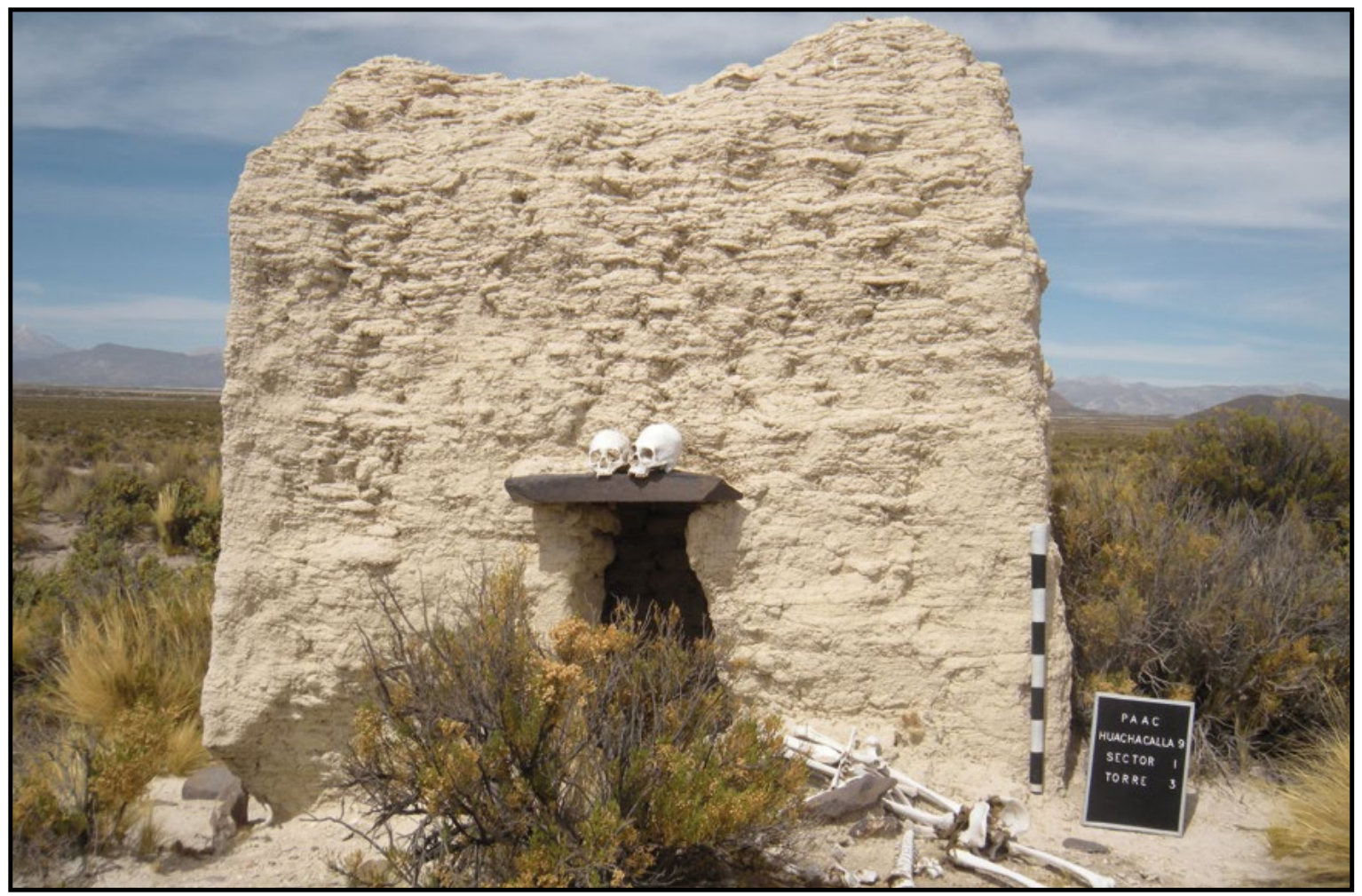

Figura 4. Cráneos de chullpas empleados en ceremonias contemporáneas en Florida, Oruro.

Recientemente, el gobierno del Movimiento Al Socialismo (MAS) promueve la refundación constitucional de Bolivia, reconociendo las cosmovisiones, prácticas y valores de las naciones indígenas. Los sindicatos agrarios se re-indigenizan, y el rol de autoridad indígena, con un capital político atractivo, es detentado por pobladores bien contactados con la cultura urbana de mercado y consumo. Coincidentemente, la última década ve la creciente patrimonialización de sitios arqueológicos, con apoyo estatal. Caso paradigmático, el willka kuti, celebración del solsticio de invierno iniciada en el sitio de Tiwanaku en los ańos setenta (Andia, 2012), actualmente convertida en feriado nacional y en escaparate turístico para los principales sitios arqueológicos del país.

Por varias razones, el arqueólogo boliviano ha sido adalid de la patrimonialización. Mediante ella las poblaciones locales 'asumen conciencia patrimonial', valorando lo que el arqueólogo valora. La patrimonialización turística es un gancho para la negociación con las comunidades, constituyendo junto al estudio de impacto, igualmente basado en el concepto de patrimonio, la mayor fuente laboral del arqueólogo. Finalmente, la visión patrimonialista, cosificada del sitio, ahuyenta al espectro del gentil, rompiendo la actitud conservadora local y permitiendo al arqueólogo operar. Por estas influencias, los chullpas se desvanecen de las ruinas, vistos por los comunarios más progresistas como 'cosas de viejos'. Así, el paradigma de desarrollo ligado al turismo, propugnado por el Estado y con el arqueólogo como aliado, viene completando la tarea colonial de destruir los vínculos relacionales entre las comunidades y un pasado nunca ausente. Para legitimar su propiedad sobre un sitio ahora cosificado como 'patrimonio' al interior de estos valores desarrollistas, las comunidades construyen nuevos discursos de ancestralidad, donde la otredad de los chullpas ya no tiene cabida.

Vistos los giros históricos de la relación que entablan los pobladores del altiplano boliviano con su pasado, resulta insostenible explicar a los chullpas mediante 
este argumento del 'otro necesario': "Constituyen ese salvaje que todo pueblo, toda cultura, necesita proyectar más allá de sus fronteras espacio-temporales para auto-afirmarse como auténticos seres humanos civilizados" (Gil García, 2005, p. 211).

Esta trasposición de una episteme dualista moderna no aplica al caso del altiplano prehispánico, donde lejos de ser 'otro' el muerto podría ubicarse en la cúspide de la escala jerárquica, en tanto representante del cuerpo social (Nielsen, 2006). La construcción del otro -el chullpa, el moro, el gentil- es fruto de un contexto colonial concreto, pleno de trasposiciones, imposiciones y violencia, donde las narraciones de gentiles conforman una auténtica literatura de adaptación (Hardman, 1984). Por ello, en un nuevo contexto ligado al aprovechamiento económico del patrimonio, el animismo reflejado por la creencia en los chullpas desaparece en favor de una nueva construcción de lo ancestral.

\section{Los abuelos y gentiles de Atacama: de otros a nosotros}

Las poblaciones del salar de Atacama y la cuenca del Loa, al norte de Chile, se adscriben a la etnia atacameña, colectividad reconocida por el Estado en el marco de las políticas multiculturales y la promulgación de la Ley Indígena de 1993. No obstante, aún persisten diferencias a nivel local, producto de sus relaciones históricas con poblaciones vecinas y sus propias particularidades socioculturales (Castro y Martínez, 1996). A pesar de dichas diferencias, tanto en el salar de Atacama como en el río Loa los sitios arqueológicos son considerados como lugares y obras de los abuelos, de los gentiles, espacios que hay que respetar y temer, en los cuales puede 'pescarte la tierra' o pueden 'agarrarte los abuelos' y producirte enfermedades, por lo que es mejor no molestarlos, no visitarlos ni tomar nada de allí (Castro y Gallardo, 1995). A esto se suman las categorías de tata-abuelos, anti-abuelos y macha-abuelos utilizadas en localidades del Loa Superior, donde además se usa la palabra chullpa para referirse a los sitios prehispánicos, la cual según Castro (1997, p. 304) corresponde con la de huaca, en cuanto alude a construcciones consideradas sagradas por haber sido hechas por los gentiles y reinka; pero además son huacas, elementos de la naturaleza culturizados.

Como vimos en subtítulos previos, el término gentil es de raigambre cristiana y evoca un momento de ruptura, el de la colonización y evangelización. Se trata de entidades de otra época, de un tiempo precristiano, contradicho al tiempo contemporáneo. Para Castro (1997, p. 303) los gentiles pertenecen además al ordenamiento local de las 'edades del mundo', a la 'generación del Rey Inca' y sus 'antecesores'. Lo que se hace extensivo a los abuelos y moros ya que aluden a los no bautizados o a "los que no tuvieron la oportunidad de conocer a Dios". Según Martínez (2010, p. 64):

Genéricamente "gentiles" designa a todas las poblaciones anteriores al advenimiento de Cristo y que, por lo tanto, no tuvieron una ignorancia culpable puesto que carecieron de la posibilidad de ser bautizados. En los Andes el término tiene también una connotación temporal: define por extensión a los habitantes de cualquier sociedad o humanidad considerada anterior a la invasión europea, es decir, gente de edades anteriores (...) y en algunos lugares están revestidos de ciertas capacidades mágicas o comunicativas con las divinidades.

En Atacama los términos gentiles, abuelos y antiguos son usados indistintamente por los lugareños y según Martínez (2010, p. 65):

Todos ellos para referirse a una humanidad que no es la actual, pero en la cual parecen entrar todos los antepasados desde la cuarta generación para atrás hasta los tiempos de rey Inka. "Gentiles" es más preciso para la gente prehispánica. En tanto que "abuelos" y "antiguos" envuelven una gran ambigüedad semántica. Curiosamente, son éstos los términos más empleados (...) "Antiguos" se usa para referirse a todo aquello sobre lo cual ya no se guarda una memoria oral. Es también un término genérico para evadir preguntas. "Es de los antiguos" implica necesariamente un desco- 
nocimiento y, por tanto, la ausencia de una explicación. Pero los “antiguos” pueden ser los propios antepasados y, los "abuelos" ya no consanguíneamente sino cronológicamente.

En el oasis de San Pedro de Atacama el término gentil es menos popular que en el río Loa, ya que es más común escuchar el de abuelos para referirse a los sitios arqueológicos. La palabra gentilar se describe tanto al sur del salar de Atacama como en el Loa Superior (Castro y Gallardo, 1995; Morales, 1997), donde además se utiliza la palabra abuelar al hablar de los sitios prehispánicos (Ayala, 2011). Para algunos lugareńos todo sitio arqueológico es gentilar, aunque otros usan esta categoría solo para referirse a aquellos 'lugares donde hay entierros y huesitos'. Algunos relatos de la localidad de Caspana marcan diferencias temporales y culturales entre gentilar y cementerio:

\section{Gentilar, en vez de cementerio, cementerio está transculturizado, que antiguamente estaban todos estos cementerios que le llamamos aho- ra, le llamaban Gentilar, que es una palabra kunza (...) Esos son Gentilares, cuando hay personas que están enterrados bajo tierra, ése es Gentilar (...) Es que por eso es que está trans- culturizados, deberian llamarse todos igual, deberian llamarse Gentilar, no cementerios. Con la llegada de los españoles cambia, le lla- man cementerio (entrevista G. G., 2008).}

Otra categoría utilizada es la de 'las almas benditas', correspondientes a una generación diferente a la de los abuelos, ya que estos últimos son los de muchos años atrás mientras las almas son recientes. En tanto las 'almas benditas' fueron bautizadas, los abuelos no recibieron la palabra de Dios. Para otros la diferencia está en que las 'almas benditas' son fallecidos conocidos y los abuelos son fallecidos desconocidos, por lo que la profundidad temporal de estos últimos se profundiza. Mientras se pueden establecer lazos de parentesco con las 'almas benditas', con los abuelos se aprecia una conexión más bien cronológica y no consanguínea (Ayala, 2011). Pero no solamente se sitúa a los abuelos en una época previa al cristianismo, sino también en lugares no compartidos con las "almas benditas" o gente de esta época. Mientras los cristianos están enterrados en los cementerios, los abuelos lo están en las 'trojas' (depósitos o tumbas prehispánicos) u otros lugares.

Las construcciones históricas de las comunidades andinas fueron dramáticamente transformadas por la conquista, especialmente por la violencia física y simbólica ejercida por la Iglesia en el proceso de extirpación de idolatrías (Duviols, 1986). Sin embargo, a pesar de ser el producto de un proceso histórico de relaciones coloniales de poder, la concepción de los abuelos y gentiles como otros y las normas sociales asociadas a los mismos forman parte de la historicidad andina desde hace varios siglos (Molinié, 1997; Bouysse-Cassagne, 1997). Además, los efectos del colonialismo en la alteridad de los abuelos y gentiles fueron funcionales al Estado-nación chileno (al igual que al boliviano antes de la Guerra del Pacífico), ya que situarlos en otro tiempo y espacio aportó al discurso negador de lo indígena. En los marcos de una política estatal asimilacionista, distanciarse de la imagen de indio implicó la negación de cualquier tipo de continuidad y vínculo con los vestigios arqueológicos como antepasados. Lo cual por lo menos fue reforzado desde la década de los ochenta en San Pedro de Atacama, cuando se identifica un mecanismo de situar lo indígena en el pasado, al designar los lugares de los abuelos como 'cosas de indios' (Ayala, 2008, 2011). Se produce entonces una triple ruptura con los abuelos: una temporal, al atribuirlos a otra época; una ontológica, al concebirlos como una humanidad distinta, y una ruptura identitaria al designarlos como indios. De esta manera, a diferencia del altiplano boliviano, en el salar de Atacama la ruptura colonial con los ancestros parece haber sido más efectiva y enajenante. Sin embargo, el caso de la localidad de Caspana en el Loa Superior evidencia algo diferente, ya que algunos miembros de esta comunidad se designaban a sí mismos como 'restos de gentiles en los años ochenta (Martínez, 2010), por lo que esta ruptura parece haber sido parcial en ciertos contextos.

La patrimonialización chilena, con los arqueólogos como protagonistas importantes, inició un proceso de transformación de las normas sociales referidas a los abuelos o gentiles. El sacerdote y arqueólogo amateur Gustavo Le Paige fue particularmente relevante en este sentido, pues vivió en San Pedro de 


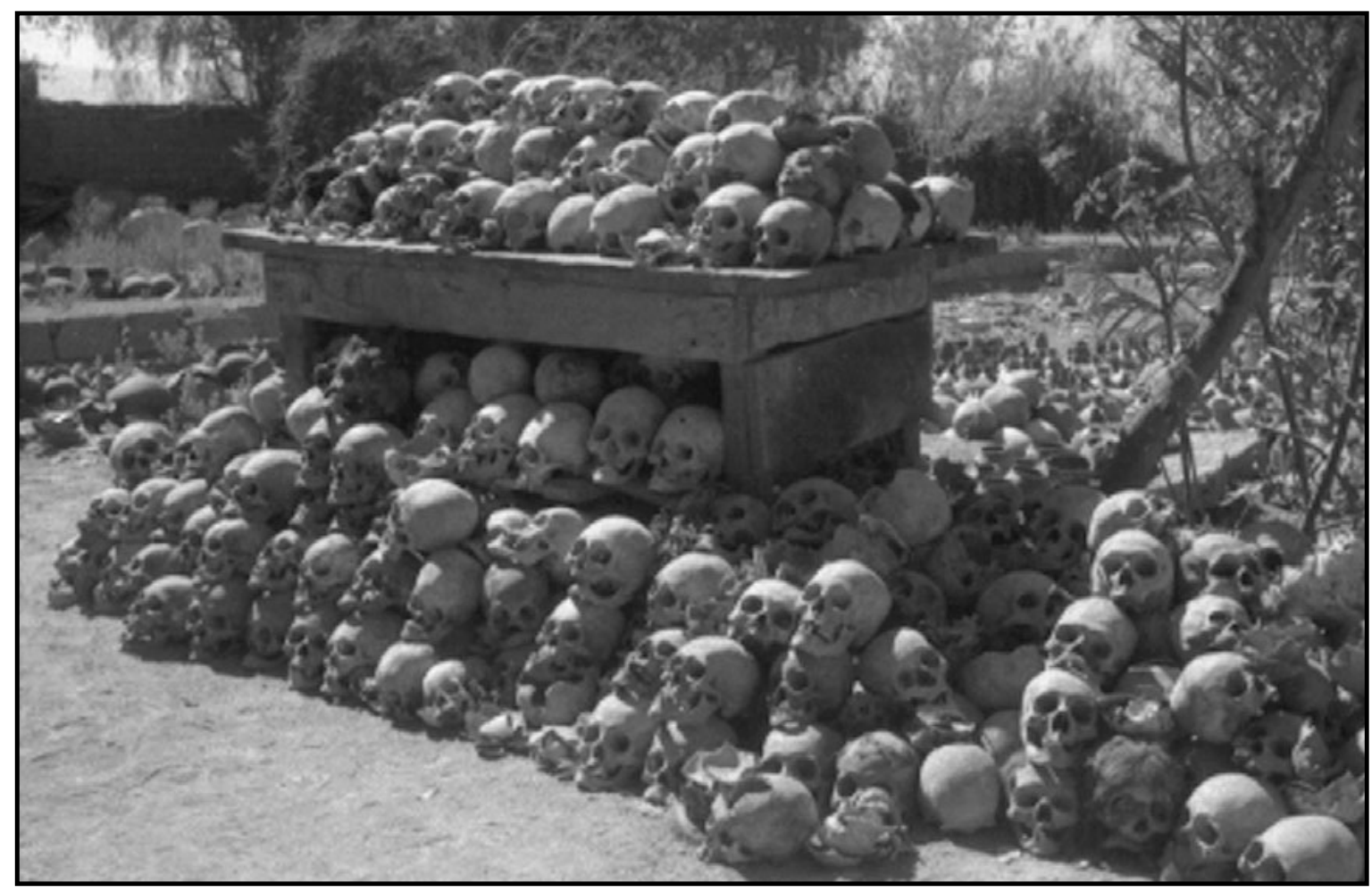

Figura 5. Colección de cráneos de los abuelos obtenida en las excavaciones de Gustavo Le Paige (Archivo I.I.A.M.)

Atacama por 26 años (para mayor información sobre Le Paige revisar Núñez, 1993; Ayala, 2008; Pavez, 2012). Durante este tiempo Le Paige excavó cientos de tumbas y sitios arqueológicos (Figura 5) sin considerar las percepciones locales referidas a los abuelos o gentiles, las cuales consideraba como supersticiones, razón por la cual en la actualidad su labor es criticada públicamente por los líderes étnicos (Ayala, 2008). Según uno de sus colaboradores atacameños, Le Paige "quería dar a conocer que los gentiles no hacian nada" (entrevista S. R., 2004), lo cual es interesante si se considera que el temor a los abuelos es producto de la acción cristiana, ya que Le Paige negó una creencia impuesta por su religión en su propio afán de excavar/extirpar idolatrías. Lo que aportó a cuestionar y cambiar una norma social de larga data en la cultura local. Si bien en algunas reuniones científicas se discutió la labor científica de Le Paige, sus sucesores continuaron excavando cementerios arqueológicos y reproduciendo relaciones coloniales de negación al ignorar y desconocer las percepciones atacameñas sobre los abuelos en San
Pedro de Atacama. Paralelamente a lo cual, en el Loa Superior un equipo de arqueólogos integró a la población local, al considerar información etnográfica en sus interpretaciones y tener en cuenta las percepciones de la comunidad en sus metodologías de investigación (Aldunate y Castro, 1981).

Con el advenimiento del multiculturalismo en los años noventa, el Estado chileno cambió su política asimilacionista y negadora de lo indígena por otra de reconocimiento y promoción de estas poblaciones, en línea con lo acontecido en otras naciones de América del Sur (Gnecco et al., 2008). En este contexto, los atacameños establecen una relación renovada con su pasado, ya que los abuelos o gentiles pasan de 'otros' a 'nosotros' y establecen una continuidad entre el pasado y el presente indígena. Con el fortalecimiento de la patrimonialización, los términos más usados por los líderes étnicos son los de abuelos y antepasados. Su utilidad radica en que la primera es una noción ambigua y puede aludir tanto a los antecesores de un grupo humano como a 
gente antigua cuyos restos materiales se encuentran distribuidos en el territorio ocupado por una población, razón por la cual es útil como herramienta de diferenciación. Algo similar ocurre con el concepto de antepasados, ya que esta noción puede referirse a ascendiente, progenitor y pariente o a gente del pasado con la cual no se tiene un vínculo familiar, pero que se asume que forman parte de la historia de una población. Diferente es el caso del término gentil, ya que inmediatamente alude a un otro y establece una diferencia o separación, por lo que es generalmente invisibilizado al menos en los discursos políticos de líderes atacameños (Ayala, 2008).

En este contexto, la patrimonialización multicultural no solo opera como dispositivo político y territorial nacionalizador, sino que produce efectos en el orden simbólico de los atacameños. A una temporalidad andina se incorpora entonces una temporalidad lineal multicultural, en la cual se conforma una relación genealógica con los abuelos que pasan de ser 'otros' a 'nosotros'. Pero también se observan tensiones y diferencias al interior de la etnia atacameña, las cuales parecen relacionarse con un acceso y apropiación diferencial de la patrimonialización a nivel local, así como con distintos ámbitos de aplicabilidad de sus discursos autorizados (el patrimonial y arqueológico) y/o con la coexistencia de identidades y memorias locales (Castro y Martínez, 1996). Algunos atacameños todavía se refieren a los abuelos o gentiles como gente de otra época y humanidad. Otros siguen insistiendo en no visitar estos lugares o afirmando que los conocieron recientemente o que nunca han estado allí.

Pese a estas tensiones y diferencias, en sus discursos políticos e identitarios los líderes atacameños se apropian del discurso estatal de continuidad histórica, construyendo una memoria indígena basada en un tiempo lineal impuesto por el nuevo nacionalismo multicultural (Boccara y Ayala, 2012). En este escenario, al igual que en el altiplano boliviano, las proscripciones sociales asociadas a los abuelos cambian profundamente, ya que los sitios arqueológicos que anteriormente no podían ser visitados actualmente son parte del mercado turístico local. Si bien algunos líderes atacameños especifican que el respeto y temor por los abuelos no se ha perdido, los proyectos de administración de sitios arqueo- lógicos evidencian las transformaciones culturales impulsadas por la patrimonialización de finales del siglo XX.

Los arqueólogos en Atacama han sido agentes centrales en este proceso al construir, reproducir y legitimar el discurso patrimonialista de la era multicultural, no solo a través de su participación en los proyectos de puesta en valor y administración de sitios arqueológicos para su uso turístico, sino también en su papel de difusores del discurso científico autorizado en cursos de capacitación y programas de educación patrimonial. En general, los arqueólogos del siglo XXI muestran un enfoque más dialógico y de consenso, coincidente con el discurso multicultural participativo de los gobiernos democráticos. Lo cual se ha materializado en experiencias de construcción de un nuevo tipo de relaciones con los atacameños, en la integración de la voz indígena, la valoración de las historias y perspectivas locales y la diversificación de los espacios de difusión del discurso arqueológico (Ayala, 2011; Kalazich, 2013; Vilches et al., 2015). No obstante, a pesar de estos avances, por lo general, la arqueología atacameña continúa subalternizando a la población indígena en proyectos de investigación o impacto ambiental en los cuales los atacameńos siguen participando exclusivamente- como excavadores o informantes claves. A la vez que son receptores de actividades de difusión en las que el discurso arqueológico continúa reproduciendo su lugar y poder de enunciación (Marcos, 2010).

\section{Conclusiones}

Para Castro-Gómez (1996), prácticamente todas las culturas, sus visiones cósmicas y sistemas de conocimiento, van asociadas a una perspectiva de totalidad. La idea de totalidad social no solo niega la diversidad, sino que la presupone y depende de la diversidad y heterogeneidad de las sociedades. Es decir, requiere la idea de otro, diferente. La particularidad de la colonialidad del poder occidental es que instituye una ruptura basada en la identidad que cambia constantemente, diferenciándose temporalmente de 'otros' pretéritos, tradicionales y anclados al pasado, cuyas identidades convierte en representaciones culturales (Grossberg, 1996). Es decir, la supresión de 
la alteridad viene seguida de la generación de representaciones culturales de diferencia.

Este artículo evidencia la necesidad de reemplazar el proceso modernizador e ilustrado de generación de diferencia por la realización de genealogías que evidencien los distintos procesos hegemónicos de subalternización, fundamentalmente la extirpación eclesiástica de idolatrías y la modernización epistémica ilustrada. La relación entre religión y ciencia es fundamental, ya que la disputa histórica entre ambos poderes se superpone a las visiones animistas del pasado. Así, personajes como Le Paige, un eclesiástico, usaban la arqueología de forma 'ilustrada' para realizar excavaciones y así mostrar que los miedos de los atacameños no eran más que supersticiones paganas. En este sentido, su paradójico trabajo llevó a la defensa de una continuidad histórica atacameña, segmentada precisamente por la ruptura colonial y la extirpación de idolatrías llevada a cabo por la Iglesia. Lo que evidencia la compleja relación entre excavación y extirpación, continuidad y ruptura, a caballo entre distintas epistemes. Así, en los casos estudiados la generación de representaciones de otredad ha supuesto la ruptura de los tejidos relacionales de las sociedades estudiadas con sus ancestros para convertirlos en representaciones culturales, es decir, en otros cargados de significados negativos o positivos.

Sin embargo, insistimos en la necesidad de evitar interpretaciones estructuralistas que entiendan la alteridad como un concepto unívoco, transhistórico y 'necesario', es decir, derivado de una suerte de necesidad humana intrínseca. Más bien mostramos cómo la generación de alteridad se produce de forma contextual dentro de campos de poder específicos, y no como un 'alter ego' resultante de las propias identidades de los grupos analizados. Los mouros no son un producto 'emic' del desarrollo sociohistórico de las comunidades, sino de relaciones de poder específicas que se impusieron para explicar un espacio y un tiempo anterior y desconocido más allá de la tradición oral. Debido a la larga duración del proceso de subalternización de las comunidades preindustriales del noroeste ibérico, el mouro 'otro' ya no es peligroso sino más bien exótico. En Atacama, tanto abuelos como gentiles fueron categorías impuestas por el poder colonial para romper la con- tinuidad histórico-cultural de las sociedades conquistadas. $\mathrm{Al}$ igual que chullpas y gentiles del altiplano boliviano, abuelos y gentiles proyectan miedos y deseos de las comunidades, pero a la vez representan fuerzas supranaturales que solo están en mano de los ancestros, como incidir en el clima o la naturaleza. Sin embargo, mientras en Bolivia los gentiles son hispanizados, en Atacama son indigenizados: los gentiles son los indios (en oposición a la identidad nacional chilena), y no los habitantes contemporáneos de Atacama. En ambos casos, los 'otros' son peligrosos, capaces de matar, pero solo son exóticos en Bolivia, al ser considerados 'hispanos'. Realidad que responde a diferentes construcciones históricas, formas de extirpación de idolatrías, particularidades nacionales y comunitarias.

Nuestra investigación evidencia las diferentes 'formaciones nacionales de alteridad' que se generan en cada contexto. En Espańa, la ausencia de políticas multiculturales y la prevalencia de una arqueología histórico-cultural y procesualista relegan el animismo al ámbito folclórico, cuando no directamente a la ignorancia del campesino rural. Con excepciones recientes como el Parque Arqueolóxico da Cultura Castrexa de San Cibrán de Lás o el Centro castreño de Lalín en Galicia, los mouros no son patrimonializados ni representados en museos, pasando los grupos sociales contemporáneos a formar parte de la alocronía. Esta implica, según Fabian (2002), una ruptura y un distanciamiento temporal con los campesinos, que pasan a representar el propio pasado de la humanidad. Es decir, pese a compartir espacio y tiempo con nosotros, los habitantes rurales dejan de ser considerados como contemporáneos, y pasan a ser representantes del pasado del propio observador -lo que implica una idea de superación del pasado (Londoño, 2012)-. Esto aplica al caso atacameño, ya que el discurso multiculturalista que incorpora a los indígenas a la historia chilena no deja de preterizarlos a través de aparatos disciplinares como la arqueología. Además, en general los arqueólogos siguen considerando a los ancestros como 'creencias locales' en contraposición a 'la verdad' científica y objetiva de su disciplina. La arqueología atacameña ha contribuido así a reproducir un discurso multicultural participativo y se ha integrado a los proyectos etnodesarrollistas del Estado. La patrimonialización de sitios arqueológicos ha llevado a formas 
de reancestralización, generando conflictos entre comunidades por la distribución de beneficios y sus diferentes nociones de propiedad privada. Como contrapunto, también se ha producido el uso de la ancestralidad como catalizador de las luchas indígenas con el Estado.

En Bolivia, los chullpas son poco tenidos en cuenta en el discurso arqueológico, debido a una disolución de las múltiples etnicidades en la narrativa de 'lo nacional' alimentada por la arqueología histórico-cultural. Ya en tiempos multiculturalistas, un Estado con participación indígena canaliza los reclamos de etnicidad a través de la concienciación de las comunidades para la puesta en valor del patrimonio, y la realización de intervenciones arqueológicas de cara a la reancestralización de los sitios. La lógica patrimonial implica un eslabón más en la escala de subalternización de lógicas animistas y pérdida de relación personal, directa, con los ancestros. El patrimonio es también un proceso totalizador, generando una representación metacultural que media en la relación con el pasado, implicando otra ruptura: se reconstruye la relación con los ancestros mediatizada por el patrimonio. A través de la patrimonialización se impone el discurso autorizado de la arqueología y se naturaliza la visión linear del tiempo, se cooptan los discursos alternativos y se los integra. Los abuelos ahora son parte de la historia comunitaria, pero se sigue reproduciendo la autoridad epistémica de la arqueología.

Contrarrestar la lógica modernista e ilustrada de subalternización y alterización implica para nosotros sacar a la luz las lógicas de producción histórica de diferencia. Esto significa reconocer el carácter necesariamente construido y contextual de cualquier identidad, y evitar así su interpretación esencialista, dualista y estructuralista. La perspectiva comparativa amplia también nos ha permitido complejizar la visión del proceso de ruptura colonial. Un proceso amplio, tanto geográfica como temporalmente, que es estudiado en ocasiones de forma fragmentaria y parcial. Pretendemos así generar más debate y evidenciar la necesidad de mayores investigaciones en el sentido propuesto en este artículo.

\section{Referencias citadas}

Aldunate, C. y Castro, V. (1981). Las chullpas de Toconce y su relación con el poblamiento altiplánico en el Loa Superior Periodo Tardio. Santiago, Chile: Kultrún.

Alonso González, P. (2015). Race and ethnicity in the construction of the nation in Spain: the case of the Maragatos. Ethnic and Racial Studies, 39(4), 614-33.

Álvarez Peña, A. (2007). Arqueología y tradición oral asturiana. En Fanjul Peraza, A. (Ed.). Estudios Varios de Arqueología castreña. A propósito de las excavaciones en los castros de Teverga (Asturias) (pp. 225-235). Teverga: Ayuntamiento de Teverga-IEPA.

Andia, E. (2012). Suma chuymampi sarnaqaña = Caminar con buen corazón: historia del Consejo de Amawt'as de Tiwanaku. La Paz: Plural.

Aparicio Casado, B. (2002). A sociedade campesiña na mitoloxía popular galega. España: Universidad Santiago de Compostela.

Arizaga Castro, Á. y Ayán Vila, X. M. (2007). Etnoarqueología del paisaje castreño: la segunda vida de los castros. En Los pueblos de la Galicia céltica (pp. 445-531). Madrid: Akal.

Arnold, D. y Yapita, J. D. (1992). Sallqa: dirigirse a las bestias silvestres en los Andes meridionales. En Arnold, D., Jiménez, D. y Yapita, J. D. (Eds.). Hacia un orden andino de las cosas (pp. 175-212). La Paz: HISBOL.

Ávila, F. (1966 [1598?]). Dioses y Hombres de Huarochirí. Lima: Instituto de Estudios Peruanos.

Ayala, P. (2008). Politicas del pasado: indigenas, arqueólogos y Estado en Atacama. San Pedro de Atacama: IIAM.

Ayala, P. (2011). La patrimonialización y la arqueología multicultural y las disputas de poder sobre el pasado indigena. Tesis Doctoral, Universidad Católica del Norte; Universidad de Tarapacá, Chile.

Balboa Salgado, A. (2005). A raina Lupa: as orixes pagás de Santiago. Santiago: Lóstrego.

Bandelier, A. (1904). The cross of Carabuco in Bolivia. American Anthropologist, 6(5), 599-628. 
Bandelier, A. (1910). The islands of Titicaca and Koati. Nueva York: Hispanic Society of America.

Bertonio, L. (1879 [1612]). Vocabulario de la Lengua Aymara. Leipzig: Teubner.

Boccara, G. y Ayala, P. (2012). Patrimonializar al indígena. Imagi-nación del multiculturalismo neoliberal en Chile. Cahiers des Amériques latines, 67, 207-228.

Bouysse-Cassagne, T. (1997). De Empédocles a Tunupa: Evangelización, hagiografía y mitos. En Bouysse-Cassagne, T. Saberes y memorias en los Andes (pp. 157-212). Lima: Institut Français d'Études Andines.

Boyle, R. (1738). A free enquiry into the vulgar notion of nature. En Shaw, P. (Ed.). The philosophical works of the Honourable Robert Boyle. Londres: W. Innys.

Briones, C. (2005). Formaciones de alteridad: contextos globales, procesos nacionales y provinciales. En Briones, C. (Ed.). Cartografias argentinas. Politicas indigenistas y formaciones provinciales de alteridad (pp. 11-43). Buenos Aires: Antropofagia.

Castro-Gómez, S. (1996). Critica de la Razón Latinoamericana. Barcelona: Puvill.

Castro-Gómez, S. (2005). La hybris del punto cero: Ciencia, raza e ilustración en la Nueva Granada (1750-1816). Bogotá: Universidad Pontificia Javeriana.

Castro, V. (1997). Huacca Muchay. Evangelización y Religión Andina en Charcas, Atacama La Baja. Tesis de Magíster, Universidad de Chile.

Castro, V. y Gallardo, F. (1995). El Poder de los Gentiles. Arte Rupestre en el Río Salado (Desierto de Atacama). Revista Chilena de Antropología, 13, 79-98.

Castro, V. y Martínez, J. L. (1996). Poblaciones indígenas de Atacama. En Hidalgo, J., Schiappacasse, V., Niemeyer, H. F., Aldunate, C. y Mege, P. (Eds.). Culturas de Chile (pp. 69-109). Santiago, Chile: Andrés Bello.

Celestino, O. (1998). Transformaciones religiosas en los Andes peruanos. 2. Evangelizaciones. Gazeta de Antropologia, 14,1-22.

Chamoso Lamas, M. (1982). Santiago de Compostela. Madrid: Sílex.
De Pina Cabral, J. y Valverde, P. J. (1989). Filhos de Adão, filhas de Eva: a visão do mundo camponesa do Alto Minho. Lisboa: Dom Quixote.

Duviols, P. (1986). Cultura andina y represión: Procesos y visitas de idolatrias y hechicerias Cajatambo, siglo XVII. Cusco: Centro de Estudios Bartolomé de Las Casas.

Fabian, J. (2002). Time and the other: How anthropology makes its object. Nueva York: Columbia University Press.

Federici, S. (2010). Calibán y la bruja, Mujeres, cuerpo y acumulación originaria. Madrid: Traficantes de Sueños.

Fernández Conde, F. J. (2000). La religiosidad medieval en España. I. Alta Edad Media, s. VII-X. Oviedo: Universidad de Oviedo.

Freán Campo, A. (2016). El imaginario de la alteridad como fuente de conocimiento arqueológico e histórico. El caso del noroeste peninsular. Gallaecia: revista de arqueoloxía e antigüidade, 34, 227-248.

Gil García, F. M. (2005). Batallas del pasado en tiempo presente. "Guerra antigua", civilización y pensamiento local en Lípez. Bulletin de l'Institut Français d'Études Andines, 34(2), 197-220.

Gil García, F. M. (2014). La cocina de los chullpas. Representaciones del pasado e identidades en el presente a partir de la alimentación en los Andes. Revista Española de Antropología Americana, 44(1), 191-215.

Gisbert, T. (1999). El paraíso de los pájaros parlantes: la imagen del otro en la cultura andina. La Paz: Plural.

Gnecco, C. et al. (2008) History and its discontents: stone statues, native histories, and archaeologists. Current Anthropology, 49(3), 439-66.

González Álvarez, D. (2011). Arqueología, folklore y comunidades locales: los castros en el medio rural asturiano. Complutum, 22(1), 133-153.

González Reboredo, X. M. (2004). Leyendas gallegas de tradición oral. Vigo: Galaxia.

Goode, J. (2009). Impurity of blood: defining race in Spain, 1870-1930. Baton Rouge: LSU Press.

Grosfoguel, R. y Mielants, E. (2006). The Long-Durée entanglement between Islamophobia and racism in the 
modern/colonial capitalist/patriarchal world-system: An introduction. Human Architecture, 5(1), 1-12.

Grossberg, L. (1996). Identity and cultural studies: is that all there is? En Du Gay, P. y Hall, S. (Eds.). Questions of cultural identity (pp. 87-107). Londres: SAGE.

Haber, A. (2009). Animism, relatedness, life: Post-Western perspectives. Cambridge Archaeological Journal, 19(3), 418-30.

Hardman, M. J. (1984). Gentiles en Cuentos Jaqi: un ejemplo de la Literatura de Contacto Cultural. Gainesville: University of Florida.

Herzfeld, M. (1992). Metapatterns: Archaeology and the uses of evidential scarcity. En Gardin, J. C. y Spalding Peebles, C. (Eds.). Representations in Archaeology (pp. 6686). Bloomington: Indiana University Press.

Ingold, T. (2013). Dreaming of dragons: on the imagination of real life. Journal of the Royal Anthropological Institute, 19(4), 734-752. doi: 10.1111/1467-9655.12062.

Isbell, W. H. y Korpisaari, A. (2012). Burial in the Wari and the Tiwanaku heartlands: similarities, differences, and meanings. Diálogo Andino, 39, 91-122.

Jiménez-Esquinas, G. (2013). Las meigas: la transformación de un estigma en recurso patrimonial. Revista de dialectología y tradiciones populares, 68(1), 57-73.

Kalazich, M. F. (2013). Cultural meanings and values of the past. A participatory approach to archaeology in the Atacameño Community of Peine, Chile. Tesis Doctoral, UCL.

Llinares García, M. (1990). Mouros, ánimas y demonios. Madrid: Akal.

Londoño, W. (2012). Espíritus en prisión: una etnografía del Museo Nacional de Colombia. Chungara. Revista de Antropología Chilena, 44(4), 733-45.

López Cuevillas, F. y Fraguas Fraguas, A. (1955). Los castros de la tierra del Saviñao. III Congreso Arqueológico Nacional, Zaragoza.

López, U. R. y Ríos, B. (1999). Las nubes de lluvias que se reproducen: exégesis del rito del ch'iwiqallu (nube que cría otras nubes). Tradición oral de Carangas. En Anales de la XIII Reunión Anual de Etnología, 59-61.
Machicado, E. (2009). Las Tumbas de la Peninsula de Taraco: Trayectorias de cambio en prácticas funerarias durante la transición entre el Formativo Medio y el Formativo Tardio. Tesis de Licenciatura, Universidad Mayor de San Andrés.

Marcos, S. (2010). La arqueología bajo la perspectiva de la comunicación: estudio de caso en San Pedro de Atacama. Tesis de Magíster, Universidad Católica del Norte. Chile.

Marín Suárez, C. (2005). Astures y Asturianos, Historiografia de la Edad del Hierro en Asturias. Serie Keltia. Noia, España: Toxosoutos.

Martínez, J. L. (2010). “Somos resto de gentiles”: El manejo del tiempo y la construcción de diferencias entre comunidades andinas. Estudios atacameños. Arqueología y Antropología Surandinas, 39, 57-70.

Molinié, A. (1997). Buscando una historicidad andina: una propuesta antropológica y una memoria hecha rito. En Varon, R. y Flores, J. (Eds.). Arqueologia, antropología e historia en los Andes. Homenaje a María Rostworowski (pp. 691-708). Lima: I.E.P.

Morales, H. (1997). Pastores trashumantes al fin del mundo. Un enfoque cultural de la tecnología: en una comunidad andina de pastores. Tesis de Grado, Universidad de Chile.

Nielsen, A. (2006). Pobres Jefes: aspectos corporativos en las formaciones sociales pre-inkaicas de los Andes Circumpuneños. En Nielsen, A., Gnecco, C. y Langebaek, C. (Eds.). Contra el pensamiento tipológico: Reflexiones teóricas actuales sobre complejidad social (pp. 121-150). Bogotá: Universidad de los Andes.

Núñez, L. (1993). Gustavo Le Paige S.J. Cronología de una misión. Antofagasta: Ediciones Universitarias del Norte.

Parinetto, L. (1998). Il Capitale e la persecuzione dei diversi. Milan: Rusconi.

Pärssinen, M. (2005). Caquiaviri y la Provincia Pacasa. La Paz: CIMA.

Pauwels, G. (1998). Los Últimos Chullpas, Alfred Métraux en Chipaya (Enero-Febrero de 1931). Eco Andino, 6, 41-82.

Pavez, J. (2012). Fetiches Kongo, momias Atacameńas y soberanía colonial. Trayectoria de Gustavo Le Paige S.J. 
(1903-1980). Estudios Atacameños. Arqueología y Antropologia Surandinas, 44, 35-72.

Polo de Ondegardo, J. (1916 [1562]). Instrucción contra las ceremonias y ritos que usan los indios conforme al tiempo de su infidelidad. En Urteaga, H. y Romero, C. Colección de libros y documentos referentes a la historia del Perú (pp. 189-204). Lima, Perú.

Ponce Sanginés, C. (1980). Panorama de la arqueología boliviana. La Paz: Juventud.

Posnansky, A. (1912). Guia general ilustrada para la investigación de los monumentos prehistóricos de Tihuanacu e islas del Sol y la Luna: (Titicaca y Koaty). La Paz: Boliviana.

Quintía Pereira, R. (2016). Análise estrutural e simbólica do mito da moura. Ourense: Fundación Vicente Risco.

Salomon, F. (1995). The beautiful grandparents: Andean ancestor shrines and mortuary ritual as seen through colonial records. En Dillehay, T. D. (Ed.). Tombs for the living: Andean mortuary practices (pp. 315-353). Washington D.C.: Dumbarton Oaks.

Sánchez, W., Bustamante, M. A. y Villanueva, J. (2015). La Chuwa del Cielo. Los animales celestiales y el ciclo anual altiplánico desde la biografía social de un objeto. La Paz: Museo Nacional de Etnografía y Folklore.

Suárez López, J. (2001). Tesoros, Ayalgas y Chalgueiros. La fiebre del oro en Asturias. Gijón: Museo del Pueblo de Asturias.

Vilches, F., Garrido, C., Ayala, P. y Cárdenas, U. (2015). The Contemporary Past of San Pedro de Atacama, Northern Chile: Public Archaeology? Archaeologies, 11(3), 372-399.

Villanueva, J. (2015). De la Pukara al Chullperío: Evaluando la articulación de comunidades imaginadas en el Carangas preinkaico. Arqueoantropológicas, 5, 23-50.

Viveiros de Castro, E. (2010). Metafisicas canibales: Lineas de antropologia postestructural. Buenos Aires: Katz. 